Praxis : Jurnal Sains, Teknologi, Masyarakat dan Jejaring | Vol. 3 | No. 2 | Maret 2021

\title{
Masalah Sosial Dalam Mecaki Katresnan Ing Satengahe Perang Politik Karya Tulus Setiyadi
}

\author{
Yosep Bambang Margono Slamet ${ }^{\mathbf{1}}$ Kristin Marwinda ${ }^{\mathbf{2}}$ \\ Fakultas Bahasa dan Budaya Universitas 17 Agustus 1945 Semarang \\ email: yosep-bambangms@untagsmg.ac.id ${ }^{1}$ \\ marwindakristin@gmail.com ${ }^{2}$
}

\begin{abstract}
Abstrak
Penelitian ini tentang masalah-masalah sosial di dalam novel berbahasa Jawa Mecaki Katresnan ing Satengahe Perang Politik (Menyusuri Cinta di Tengah Perang Politik) karya Tulus Setiyadi. Tujuan penelitian ini adalah untuk mendeskripsikan masalah-masalah sosial yang ada di dalam novel. Penelitian dilakukan dengan menggunakan metode kualitatif dengan analisis holistik-deskriptif dan teori yang digunakan adalah teori sosiologi sastra. Teori ini tidak memiliki fokus pada kualitas atau baik-buruknya novel ini sebagai karya sastra melainkan pada isinya yang terkait dengan permasalahan yang ada di dalam masyarakat. Hasil penelitian menunjukkan bahwa dalam novel ini terdapat permasalahan sosial yang berkaitan dengan jurang pemisah antara kelompok masyarakat yang kaya dan miskin, kekuasaan, dan hubungan percintaan.
\end{abstract}

Kata kunci: sastra Jawa, masalah sosial, politik, kekuasaan, percintaan

\begin{abstract}
The research is about social problems in Mecaki Katresnan ing Satengahe Perang Politik (Living the Love during the Poltical War), a novel in Javanese by Tulus Setiyadi. The purpose of this research is to describe social problems in the novel. The research was conducted using the qualitative method with holistic-descriptive analysis and the theory used was the sociological theory of literature. This theory does not focus on the literariness quality of this novel as a literary work but on its content in relation to problems that exist in Javanes contemporary society. The results showed that in this novel there are social problems related to the gap between the rich and poor, power, and love relationship.
\end{abstract}

Keywords: Javanese literature, social problems, politics, power, love relationship

\section{PENDAHULUAN}

Artikel ini membicarakan tentang permasalahan sosial dalam novel Mecaki Katresnan ing Satengahe Perang Politik (Menyusuri Cinta di Tengah Perang Politik) yang selanjutnya disingkat MKISPP (Setiyadi, 2019). Novel ini merupakan salah satu karya sastra Jawa modern yang terbit menjelang pemilihan presiden dan anggota legislatif tahun 2019 yang lalu. Di dalamnya terdapat berbagai permasalahan sosial yang terkait dengan kehidupan sehari-hari dan politik dalam negeri Indonesia dalam jalinan kisah cinta yang dialami oleh tokoh utamanya. Termasuk di dalamnya adalah masalah kemiskinan penduduk desa yang juga tercermin dalam sosok tokoh utama dan keluarganya. Kemiskinan ini ternyata bisa menjerumuskan manusia ke dalam perbuatan-perbuatan dengan moralitas rendah. 
Novel MKISPP ini menunjukkan kepada kita pembaca bahwa karya sastra tidak bisa dilepaskan dari masyarakatnya. Baik pengarang, pembaca, maupun isi sebuah karya sastra tidak pernah bisa lepas dari konteks sosial, budaya, dan politik masyarakat tersebut (Abrams, 1953; Calinescu, 1982; Clark, 1982; Wellek \& Warren, 1956). Paling tidak dalam tiga pendekatan yang digagasnya, yakni pendekatan pragmatik, ekspresif, dan mimetik, Abrams menguraikan hubungan antara karya sastra dengan masyarakatnya - dengan seluruh konteks sosial dan kebudayaan dalam arti luas. Demikian pula, dalam konsepnya tentang pendekatan ekstrinsik terhadap karya sastra, Wellek dan Warren juga melihat hubungan yang sangat erat antara karya sastra dengan masyarakatnya. Berbeda dari Abrams, Wellek dan Warren, Calinescu secara khusus menyoroti kaitan antara sastra dengan sosiologi; sementara Clark berbicara tentang kaitan antara sastra dan politik.

Sastra Jawa, apakah itu sastra Jawa kuno, pertengahan maupun modern-seperti halnya karya sastra mana pun pada umumnya - dengan demikian juga tidak bisa dilepaskan dari konteks masyarakatnya. Sekalipun sastra bukan dokumen sosial melainkan karya seni, sastra Jawa juga banyak "merekam" berbagai peristiwa yang terjadi dalam masyarakat Jawa khususnya dan Indonesia pada umumnya. Bahkan dalam sastra Jawa modern, dengan jelas kita bisa melihat bahwa para pengarang sastra Jawa banyak menulis karya dengan menggali materi cerita yang bersumber dari masyarakat Jawa sendiri, masyarakat yang mereka ketahui dengan sangat baik atau masyarakat yang mereka akrabi. Di dalam bertutur tentang kisah-kisah mereka itulah, para pengarang sastra Jawa tidak hanya menceritakan apa yang terjadi dalam masyarakat melainkan juga memberikan kritik terhadap berbagai permasalahan yang ada. Pengarang-pengarang tersebut antara lain Suparta Brata, Krishna Miharja, A.Y. Suharyono, Turiyo Ragilputra, Suwardi Endraswara, dan masih banyak lagi (Margono, 2019).

Penelitian ini mengambil topik permasalahan sosial dalam novel MKISPP karya Tulus Setiyadi karena novel ini mengandung berbagai permasalahan aktual terutama masalah sosial politik di Indonesia menjelang pemilihan presiden, wakil presiden dan anggota legislatif pada tahun 2019 yang lalu. Oleh sebab itu, penelitian ini tidak terfokus pada aspek kesastraan melainkan pada aspek sosial karya sastra, dalam arti sejauh mana novel ini mencerminkan berbagai permasalahan yang ada di dalam masyarakat Jawa. Artinya, secara literer, apakah novel ini merupakan novel yang baik atau tidak, menjadi tidak penting. Dengan demikian analisis dalam penelitian ini bukan merupakan analisis literer untuk menilai baik buruknya novel ini sebagai karya sastra.

Dengan latar belakang pemikiran seperti ini, tujuan penelitian ini adalah untuk mendeskripsikan permasalahan sosial yang ada di dalam novel MKISPP yang mencerminkan terutama kehidupan masyarakat Jawa pedesaan pada saat ini. Bukan hanya masyarakat perkotaan yang mengalami berbagai masalah, melainkan juga masyarakat pedesaan. Pengaruh media sosial, perilaku konsumtif, jurang pemisah antara kaya dan miskin, dan keinginan untuk berkuasa bukan hanya monopoli masyarakat perkotaan melainkan juga sudah terjadi dalam dan/atau menjadi obsesi masyarakat pedesaan. Hal-hal inilah yang dibicarakan dalam penelitian ini.

Penelitian ini diharapkan memberikan tambahan referensi tentang penelitian sosiologi sastra Jawa modern. Seperti halnya sastra Indonesia dan sastra lainnya, sastra Jawa modern merupakan sastra yang kaya dengan permasalahan masyarakatnya. Banyak pengarang baru bermunculan 
menggantikan pengarang senior yang sudah tidak berkarya lagi atau menggantikan mereka yang sudah meninggal dan para pengarang baru ini memiliki pandangan baru mengenai masyarakat Jawa lewat karya-karya mereka. Tulus Setiyadi merupakan salah satu pengarang Jawa generasi baru (sebenarnya sudah menulis cukup lama, tetapi dia mulai dikenal karena produktivitasnya yang sangat tinggi setelah tahun 2015). Sekalipun banyak karyanya sudah diteliti oleh para peneliti lain, sejauh pengetahuan peneliti, novel MKISPP ini belum diteliti.

\section{TELAAH LITERATUR}

Tulus Setiyadi adalah seorang sastrawan Jawa dari Madiun yang sangat produktif dalam menulis novel. Karya-karyanya sudah banyak yang dijadikan bahan penelitian (Aisyah \& Widodo, 2019; Ardiyanti, Sulanjari, \& Zaidah, 2020; Astutik \& Hasan, 2018; Cahya, 2017; Harjani, Suwandi, \& Wardhani, 2018; dan Murendra, 2020).

Aisyah dan Widodo (2019) dan Cahya (2017) meneliti novel Juminem Dodolan Tempe dengan pendekatan yang berbeda. Aisyah dan Widodo menggunakan pendekatan feminisme sedangkan Cahya menggunakan pendekatan sosiologi sastra. Ardiyanti, Sulanjari, dan Zaidah (2020) dan Astutik dan Hasan (2018) meneliti novel yang sama, Cinencang Lawe. Astutik dan Hasan menggunakan pendekatan psikologis sementara Ardiyanti, Sulanjari, dan Zaidah menggunakan pendekatan sosiologis. Sedangkan penelitian lain yang disebutkan di atas meneliti novel yang berbeda lagi.

Belum banyaknya penelitian terhadap novel yang sama adalah karena novelnovel karya Tulus Setiyadi merupakan novel-novel baru. Peneliti sudah mencoba mencari studi terdahulu mengenai novel MKISPP (terbit Maret 2019) namun hingga tulisan ini dibuat, penelitian tentang novel ini belum ada. Peneliti belum menemukan artikel atau jurnal ilmiah tentang novel ini. Dengan demikian penelitian ini merupakan penelitian pembuka tentang novel ini.

\section{LANDASAN TEORI}

Secara tradisional ada empat pendekatan atau teori sastra yang biasa digunakan oleh para peneliti sastra, yakni obektif, mimetik, ekspresif, dan pragmatik (Abrams, 1953). Pendekatan obyektif menganggap karya sastra sebagai dunia otonom yang tidak terkait dengan dunia di luar karya sastra. Dengan demikian, dalam pendekatan ini, sastra merupakan dunia tersendiri yang memiliki makna berdasarkan unsur-unsur yang membangunnya seperti plot, karakter dan karakterisasi, latar, tema, dan sudut pandang. Pendekatan mimetik menganggap sastra sebagai tiruan kenyataan. Dalam konsep Plato, kenyataan adalah dunia ide yang ideal. Dengan demikian karya sastra tidak akan pernah menyamai dunia ide yang ideal tersebut. Mimesis dalam konsep Plato ini bisa dianggap berkonotasi negatif karena pengarang hanya mampu meniru dan selamanya tiruan tidak akan pernah bisa lebih baik daripada aslinya. Sementara itu Aristoteles, murid Plato, memberikan makna yang berkonotasi positif. Menurut Plato, sastra bukan semata-mata tiruan kenyataan melainkan penciptaan kembali kenyataan (recreation of reality). Jadi tiruan di sini bukan semata-mata meniru atau menjiplak melainkan menciptakan kembali kenyataan di dalam karya sastra (Ratna, 2011). Sementara itu, pendekatan ekspresif menyatakan bahwa karya sastra adalah ekspresi pengarangnya. Dalam pendekatan ini, biografi pengarang, pandangan hidup atau idelogi yang dianutnya, pemikiran-pemikiran serta keresahan-keresahannya merupakan faktor penting bagi penelitian ekspresif ini. 
Sedangkan pendekatan pragmatik lebih terfokus pada seberapa besar manfaat karya sastra bagi para pembacanya.

Dari keempat pendekatan klasik Abrams ini, bisa disimpulkan bahwa hanya pendekatan obyektif yang tidak memerlukan rujukan masyarakat di luar karya sastra untuk menelaahnya, sekalipun karya sastra itu bertutur tentang para anggota suatu masyarakat. Tiga pendekatan lainnya, mimetik, ekspresif, dan pragmatik, terkait dengan masyarakat. Telaah mimetik, ekspresif, atau pragmatik karya sastra pasti akan melibatkan pembicaraan tentang masyarakatnya, atau sekurang-kurangnya pengarangnya yang merupakan anggota masyarakat di mana dia hidup dan/atau berkarya.

Di sisi lain, Wellek dan Warren (1956) merumuskan dua teori besar yakni teori instrinsik dan ekstrinsik. Teori intrinsik Wellek dan Warren ini bisa disamakan dengan teori obyektif Abrams, yakni meneliti karya sastra dari unsur-unsur yang membangunnya seperti yang sudah disebutkan di atas. Sementara itu, teori ekstrinsik secara garis besar membicarakan hubungan sastra dengan biografi (pengarangnya), dengan masyarakat, dengan psikologi, dengan ide-ide, dan juga dengan bentuk-bentuk seni lainnya.

Di samping pendekatan atau teori klasik yang dirumuskan oleh Abrams serta oleh Wellek dan Warren, teori atau pendekatan sastra selalu berkembang sehingga sekarang ini kita kenal adanya teori feminisme, teori poskolonial, teori dekonstruksi, teori respons pembaca, teori postmodern dan masih banyak lagi (Ratna, 2011). Tetapi terkait dengan penelitian ini, tentang masalah-masalah sosial dalam novel MKISPP, peneliti hanya akan mengacu pada dan mengaplikasikan teori sosiologi sastra.

\section{Sosiologi Sastra}

Istilah sosiologi sastra sering juga disebut dengan pendekatan sosiologis atau teori sosiologi sastra. Namun demikian perlu dicermati bahwa Abrams (1953), dan Wellek dan Austin (1956) tidak menggunakan istilah ini. Wellek dan Austin menyebutnya hubungan antara sastra dan masyarakat (literature and society), sementara Abrams tidak secara eksplisit menyebutkannya sekalipun tiga teorinya, selain obyektif, bisa kita kategorikan ke dalam teori ini.

Dalam konsep Wellek dan Warren, sastra dan masyarakat atau dalam penelitian sastra lazim digunakan istilah sosiologi sastra atau teori sosiologi sastra, teori ini mencakup tiga ranah: (1) sosiologi pengarang; (2) sosiologi karya; dan (3) sosiologi pembaca. Dari tiga kategori ini kita bisa memahami bahwa cakupan karya sastra dan masyarakat begitu luas.

Clark (1982) secara khusus menulis tentang sastra dan sosiologi yang sebenarnya mengacu pada hubungan antara sastra dan masyarakat. Dia menyebutkan bahwa sastra adalah diskursus sosial. Diskursus sosial ini dibentuk oleh berbagai hubungan yang kompleks di dalam masyarakat, baik itu dari pihak pengarangnya maupun pembacanya. Oleh sebab itu tugas sosiologi sastra adalah menjelaskan signifikansi sastra dalam konteks sosial. Dengan sosiologi sastra kita akan bisa memahami kompleksitas dan relasi sosial yang tidak ada akhirnya.

Sementara itu Calinescu (1982) menyoroti secara khusus hubungan antara sastra dan politik. Dia antara lain menyatakan bahwa sastra tidak bisa dilepaskan dari politik karena pengarang, secara sadar atau tidak, memiliki komitmen politik. Pengarang memiliki keterlibatan, apakah terhadap penguasa atau terhadap rakyat. Sekalipun ada pengarang yang menyatakan bahwa dia tidak memiliki komitmen atau 
keterlibatan, sikap seperti itu sudah merupakan sikap politik.

Konsepsi Calinescu ini penting untuk menganalisis novel MKISPP karena novel ini sarat dengan peristiwa politik praktis. Paling tidak ada dua tokoh dalam novel ini yang maju menjadi calon wakil rakyat dan juga ayah tokoh utama dulunya adalah orang yang berkecimpung di dalam partai politik dan karena kesalahan yang dilakukannya dia tersingkir atau disingkirkan dari partainya dan hidup melarat. Melalui pemikiran Calinescu ini kita akan melihat dengan mendalam kritik sosial Setiyadi terhadap masyarakat Jawa modern. Di Indonesia, teori sosiologi sastra ini sangat populer. Para ilmuwan sastra Indonesia bisa saja memiliki rumusan sedikit berbeda tetapi intinya sama, yakni bahwa sosiologi sastra merupakan alat bantu untuk menelaah karya sastra dalam kaitannya dengan masyarakat. Endraswara (2011), Faruk (2017), Ratna (2003), dan Wicaksono (2014), misalnya, juga mengadopsi teori Wellek dan Warren yang sudah dijelaskan di atas dan menjadi rujukan para peneliti sastra di Indonesia.

Cakupan teori sosiologi sastra ini sangat luas karena mencakup sosiologi pengarang, sosiologi karya, dan sosiologi pembaca. Tetapi aplikasi teori sosiologi sastra dalam penelitian ini hanya dibatasi pada sosiologi karya, dalam arti peneliti hanya membicarakan, menganalisis, dan mendeskripsikan masalah-masalah sosial yang ada di dalam novel MKISPP. Kalaupun dalam penelitian ini digunakan juga istilah kritik sosial, kritik sosial di sini merupakan interpretasi peneliti terhadap novel ini, bukan kritik sosial yang langsung diperoleh dari atau disampaikan oleh pengarang melalui metode wawancara. Hal ini secara rinci dibahas di bagian berikut ini.

\section{METODE PENELITIAN}

Metode penelitian ini adalah metode kualitatif. Moleong (2007) antara lain menyatakan bahwa penelitian kualitatif adalah penelitian untuk memahami fenomena secara holistic-deskriptif dalam bentuk kata-kata. Dalam penelitian ini, peneliti memahami fenomena yang ada di dalam novel MKISPP secara holistik dengan cara mendeskripsikannya.

Data penelitian berupa satuan peristiwa dalam bentuk dialog (kalimat) dan paragraf yang terdapat dalam teks novel MKISPP karya Tulus Setiyadi, yang memuat informasi untuk menganalisis permasalahan penelitian dan berkaitan dengan tujuan penelitian. Sumber data primer berupa teks novel MKISPP karya Tulus Setiyadi. Instrumen penelitian ini adalah peneliti sendiri yang memiliki pengetahuan tentang seperangkat teori dan konsep mengenai unsur intrinsik dan ekstrinsik karya sastra, sosiologi sastra, masalah sosial dan kritik sosial. Metode dan teknik pengumpulan data penelitian ini dilakukan dengan membaca secara mendalam, kemudian mencatat kalimat dan/atau paragraf atau bagian novel yang terkait dengan perumusan masalah dan tujuan, kemudian mereduksi dan menghubungkan data dengan situasi dan kondisi yang ada di dalam masyarakat.

Metode dan teknik analisis data dilakukan dengan cara mendeskripsikan data (dari novel) yang kemudian disusul dengan analisis. Dengan metode ini, peneliti tidak hanya menguraikan masalah sosial yang ada di dalam novel MKISPP tetapi juga memberikan pemahaman dan penjelasan secukupnya (Ratna, 2008:53). Metode analisis deskriptif digunakan untuk mendeskripsikan data-data tentang masalah sosial yang terdapat dalam teks novel MKISPP kemudian dilanjutkan dengan menganalisisnya. 


\section{HASIL PENELITIAN DAN PEMBAHASAN}

Secara garis besar, hasil penelitian mengenai masalah-masalah sosial yang ada ada di dalam MKISPP bisa dikelompokkan ke dalam tiga ketegori berikut: jurang pemisah antara kaya dan miskin, kekuasaan, dan cinta dalam politik dan kekuasaan. Ketiga permasalahan ini saling terkait satu sama lain. Namun demikian, untuk menganalisisnya, masing-masing kategori diuraikan secara terpisah berikut ini.

\section{Jurang Pemisah antara Kaya dan Miskin}

Tokoh utama novel MKISPP, Erna, terlahir dari keluarga miskin. Orang tuanya, Lamin dan Dinah, merupakan petani kecil di sebuah desa di wilayah Madiun. Erna yang duduk di kelas XII SMU digambarkan sebagai seorang gadis yang keras kepala, tidak taat pada orang tua, dan ingin hidup enak atau mewah. Tetapi keinginan itu tidak menjadi kenyataan karena orangtuanya memang tidak mampu. Mereka hanya hidup paspasan dari hari ke hari dengan bekerja keras di sawah dan ladang mereka. Dalam konteks yang lebih luas, keluarga Lamin bisa diinterpretasikan mewakilik golongan masyarakat yang miskin.

Di sisi lain, ada dua tokoh yang digambarkan berasal dari keluarga kaya, yakni Rafa dan Hasto. Rafa adalah seorang pemuda satu desa dengan Erna, sementara Hasto berasal dari desa lain. Kedua tokoh ini bisa dianggap merepresentasikan kelompok masyarakat kaya. Rafa dan Hasto dikisahkan memiliki mobil dan memiliki banyak uang dan mereka berdua adalah hedonis. Dalam novel ini, Erna dikisahkan memiliki hubungan dengan kedua orang ini.

Dalam sastra Jawa modern, persoalan jurang pemisah antara kaya dan miskin ini bukan merupakan topik baru melainkan bisa dikatakan sebagai topik abadi. Para pengarang Jawa rata-rata adalah PNS (guru) dan perangkat desa atau pensiunan guru dan perangkat desa danmereka ratarata akrab dengan penduduk pedesaan Jawa yang miskin. Penggambaran masyarakat desa yang miskin ini tidak hanya ada di dalam novel melainkan juga di dalam cerita pendek dan puisi Jawa modern (untuk uraian yang lebih detil, lihat misalnya Margono, 2020).

Dengan demikian, apa yang dialami atau terjadi pada Erna dan kedua orangtuanya, Lamin dan Dinah, serta adik laki-lakinya, Alif, ini bukan sesuatu yang luar biasa dalam novel MKISPP ini karena secara umum, masyarakat Indonesia, termasuk masyarakat pedesaan di Jawa, masih didominasi oleh kelas bawah. Ansori (2020) menyatakan bahwa Indonesia masih merupakan negara berkembang dan salah satu cirinya adalah struktur sosial ekonomi Indonesia saat ini memang masih didominasi oleh kelas bawah. Ansori mengutip data Bank Dunia yang menyatakan bahwa saat ini kelas bawah (79\%), kelas menengah (20\%) dan kelas atas (kurang dari 1\%).

Sebagai pengarang, Tulus Setiyadi tidak memiliki kewajiban untuk menyelesaikan masalah kemiskinan ini melainkan menggambarkan kondisi ini dalam kisah yang diceritakannya. Kutipan berikut ini menggambarkan kemiskinan tokoh utamanya:

Lagi wae nedheng-nedhenge tandang gawe HP-ne muni. Age-age dicandhak lan ditiliki whatsap sing mlebu. Jebul kancakancane ngajak metu menyang warung angkringan. Mesthi wae Erna semu bingung, awit ora duwe dhuwit. Bareng dikabari menawa iki mengko ana sing mbayari kabeh, kaya disawatake wae anggone tandang gawe ... (h. 19) 
(Baru saja sibuk bekerja HP-nya berbunyi. Segera saja dia meraihnya dan membaca pesan WhatsApp yang masuk. Ternyata teman-temannya mengajaknya ke warung angkringan. Tentu saja Erna bingung karena tidak punya uang. Setelah diberitahu bahwa ini nanti ada yang membayar untuk semuanya, dia bekerja dengan sangat cepat ...)

Namun demikian, ada perubahan yang menyolok dalam masyarakat Jawa pedesaan saat ini. Sekalipun miskin, masyarakat pedesaan Jawa tetap memiliki smartphone dan menggunakan media sosial. Dengan demikian, kepemilikan smartphone dan penggunaan media sosial tidak bisa dijadikan ukuran bahwa seseorang secara sosial ekonomi bisa dikatakan kecukupan.

Secara tradisional, masyarakat di Jawa dikenal sebagai masyarakat yang nrima ing pandum, bisa menerima keadaan apa adanya. Tetapi dalam novel ini, Erna, sebagai tokoh utama, digambarkan sebagai seorang gadis desa Jawa modern yang tidak bisa menerima keadaannya. Dia melakukan hal-hal yang 'di luar nalar' untuk memberontak kemiskinannya sekalipun pemberontakan yang dilakukannya itu melanggar norma ssosial Jawa dan juga norma agama. Dengan mudahnya dia menyerahkan diri kepada Hasto dan Rafa (akan diuraikan secara rinci dalam subbab Hubungan Percintaan di bawah nanti).

Jurang pemisah antara Erna di satu pihak dan Rafa serta Hasto di pihak lain tidak mudah dijembatani. Kalau Erna, Rafa dan Hasto merupakan representasi penduduk pedesaan Jawa, kelompok Erna, seperti dinyatakan oleh Ansori (2020) jauh lebih besar. Dengan kata lain, mayoritas penduduk pedesaaan Jawa saat ini masih miskin. MKISPP hanyalah salah satu dari banyak karya sastra Jawa yang bertutur tentang persoalan ini.

\section{Kekuasaan}

Kekuasaan menjadi obsesi banyak orang, termasuk obsesi masyarakat pedesaaan saat ini. Sejak runtuhnya Orde Baru dan kita memasuki era reformasi, masyarakat kita menjadi begitu bebas dan begitu banyak orang yang dulunya merasa tertekan oleh penguasa kini ingin berkuasa. Pengarang sastra Jawa pasca Orde Baru banyak yang menulis tentang topik ini (Hartanto, 2003; Kinatri, 2003; Masdjup, 2003; Ragilputra, 2007; Sudadi, 2003a, 2003b, dan Suharyono, 2001) untuk menyebut beberapa contoh saja.

Represi Orde Baru yang begitu lama dan intensif membuat banyak orang merasa memiliki kebebasan yang begitu besar dan mereka pun memiliki impian untuk menjadi penguasa. Salah satu sebab utama mengapa mereka ingin berkuasa atau menjadi penguasa adalah karena, menurut Al Hafis dan Yogia (2017), mereka akan bisa mempengaruhi orang lain dan mencapai apa yang mereka inginkan. Karena motivasi seperti inilah, kita menghadapi kenyataan bahwa banyak penguasa menyalahgunakan kekuasaan mereka (melakukan abuse of power) di semua tingkat atau jenjang dan jenis jabatan publik yang ada di negara kita.

Kekuasaan ini menjadi isu penting dalam MKISPP. Seperti sudah dijelaskan di atas bahwa novel ini terbit pada bulan Maret 1919, sebelum pemilihan umum untuk memilih presiden, wakil presiden, dan anggota legislatif pada bulan April 2019 yang lalu. Untuk membicarakan isu kekuasaan dalam novel ini, kita mulai dari Lamin, ayah Erna.

Sewaktu mudanya, Lamin adalah anggota partai yang hidupnya mapan. Sebagai pengurus partai, apa yang diucapkannya begitu berpengaruh terhadap masyarakat. Menurut Dinah, istrinya, dengan berkatakata saja, suaminya bisa menghasilkan uang pada waktu itu. Tetapi Lamin, yang 
sudah beristri kemudian selingkuh dengan istri teman separtainya dan dia disingkirkan dari partai tersebut. Sejak itulah hidupnya berubah total. Dia harus bekerja keras memeras keringat untuk sekedar menghidup keluarganya. Maka dia pun pindah ke desa dan memulai hidup baru. Tetapi justru peristiwa itulah yang membuatnya sadar bahwa dia harus menjadi suami dan ayah yang bertanggung jawab terhadap keluarganya. Dia menjauhkan diri dari politik praktis dan mengubur semua yang pernah dia alami.

Jaman berganti. Orde Baru tumbang. Indonesia menjadi negara demokratis yang mengakomodasi keinginan semua warga negaranya yang memenuhi syarat untuk menduduki jabatan-jabatan publik. Maka sampailah pada pemiliihan umum tahun 2019.

Rafa, seorang pemuda yang baru lulus sekolah, mencalonkan diri menjadi anggota legislatif. Tidak dikisahkan secara ekslisit oleh Tulus Setiyadi dia berasal dari partai apa dan maju sebagai calon anggota DPRD Provinsi atau Kabupaten Kota. Tulus Setiyadi mengisahkan dengan panjang lebar bahwa Rafa tidak atau belum memiliki pengalaman politik sama sekali karena masih terlalu muda. Namun karena dia anak orang kaya, dia diminta oleh partainya untuk maju sebagai calon anggota DPR. Seperti sudah menjadi pengetahuan kita bersama, Rafa tentu saja membayar mahar yang besar kepada partainya agar dia bisa dicalonkan.

Sekalipun Lamin sudah mundur dari dunia politik praktis, dia masih tetap setiap dengan ideologi partainya yang tetap berlandaskan pada Pancasila dan UUD 1945. Sebaliknya, Rafa merupakan anggota partai yang oleh Lamin disebut sebagai partai yang ingin mengganti ideologi negara; dan ini menjadi penyebab buruknya hubungan mereka, seperti yang bisa kita lihat dari kutipan ini :
... Emane kabeh ora gelem mawas lan nyawang marang sejarahe bangsa. Adegadege nagara kang wujude Pancasila lan UUD 1945 malah arep dohoyag-hoyag niyat diganti ideologi liya. Bocah saiki akeh sing ora ngerti, awit mung paitan politikus karbitan. Sangu tekad kang kuwat lan rai gedheg ngrabasang turut desa lan kutha-kutha nyebarake ideologine kanthi kudhung agama. Banjur Gusti didol jenenge lan agama diobok-obok. Kaya ngono sing disumelangake Pakdhe Lamin marang bocah-bocah kaya Rafa sing satemene isih cubluk marang jagade politik apamaneh paugerane nagara (hh. 57-58).

(Sayang sekali semua orang tidak mau mawas diri dan melihat kembali sejarah bangsa. Dasar negara Pancasila dan UUD 1945 akan digoyang dengan niyat untuk diganti dengan ideologi lain. Anak-anak sekarang tidak banyak tahu soal ini karena mereka hanya berbekal pengetahuan dari para politikus karbitan. Mereka hanya memiliki keinginan yang besar dan muka tebal tidak tahu malu menerabas desa dan kota menyebarkan ideologi mereka dengan bungkus agama. Lantas Tuhan dijual nama-Nya dan agama diobok-obok. Demikianlah yang dikhawatirkan Pakde Lamin terhadap anak-anak muda seperti Rafa yang masih belum memahami dunia politik apalagi aturan negara).

Perbedaan pandangan politik inilah yang membuat Rafa dan Pakde Lamin tidak bisa akur. Apalagi ketika pada akhirnya Pakde Lamin mengetahui bahwa Erna hamil karena perbuatan Rafa. Kebenciannya pada pemuda itu memuncak.

Di sisi lain, Hasto, yang juga anak orang kaya, memiliki keinginan yang sama dengan Rafa, maju menjadi calon anggota DPR. Tetapi dia dari partai yang berbeda. Dikisahkan dalam novel, tidak ada kontak langsung antara Pakde Lamin dengan Hasto sehingga tidak terjadi konflik langsung di antara keduanya. Hanya Erna 
yang mempunyai kontak langsung dengan keduanya.

Selain mengisahkan cerita tentang orangorang yang menginginkan kekuasaan untuk kepentingan diri sendiri seperti Rafa dan Hasto, sebagai pengarang Tulus Setiyadi juga memberikan pandangan dan kritiknya terhadap kekuasaan yang korup. Seperti yang dijelaskan oleh Calinescu (1982), setia pengarang memiliki keberpihakan dan mayoritas atau bahkan semua pengarang Jawa memiliki keberpihakan pada rakyat kecil. Keberpihakan Tulus Setiyadi ini dia sampaikan melalui narasi maupun dialog-dialog di antara para tokohnya, seperti yang terlihat dalam dialog antara Erna dan Mbok Dinah, ibunya, ini :

«Banjur nasibe wong cilik kaya awake dhewe iki kepiye?»

«Mesthi wae manggon ana ngisor kerep diasorake. Saben dina kanggo ancik-ancik. Sing gawe larane ati, mung diapusi karo sing ana ing ndhuwur. Sangune ulat lamis, adol umuk lan rai gedheg.» (h. 67)

(«Lalu nasib wong cilik seperti kita ini bagaimana nanti?»

«Tentu saja karena kita berada di bawah tentu tidak dianggap dan selalu dipandang rendah. Yang menyakitkan, kita hanya ditipu sama yang di atas. Mereka hanya bermodalkan kepalsuan, jualan kesombongan dan muka tembok.»)

Penggalan dialog antara Erna dan ibunya di atas merupakan salah satu masalah sosial politik yang ada di negara kita sebagai akibat dari demokrasi yang kebablasan. Bagi sebagian besar rakyat kecil, siapa pun yang duduk di pemerintahan dalam berbagai jenjang selalu akan dipahami sebagai orang-orang yang berkuasa untuk kepentingan diri pribadi dan kelompok mereka. Lewat Pakde Lamin pula, Tulus Setiyadi menyatakan rasa prihatinnya karena memang dalam dunia politik di Indonesia, ada partai yang orang-orangnya ingin menggantikan ideologi negara. Apakah dia sadari atau tidak, Tulus Setiyadi sebagai pengarang memiliki keterlibatan atau komitmen sosial politik di dalam karyanya ini.

\section{Cinta dalam Politik dan Kekuasaan}

Seperti judulnya, Mecaki Katresnan ini Satengahe Perang Politik, novel ini berkisah tentang percintaan antara Erna, Hasto, Rafa, dan Bagus yang terjalin dengan cerita tentang politik, kekuasaan, dan jurang pemisah antara kaya dan miskin, antara wong cilik dengan penguasa atau para pejabat negara, termasuk cerita tentang kekuasaan yang menjadi obsesi bagi banyak orang.

Hubungan percintaan yang terjalin di tengah masalah politik dan kekuasaan memunculkan berbagai konflik dalam kehidupan tokoh utama dengan tokohtokoh lainnya. Terkait dengan hubungan percintaan ini, Erna, tokoh utamanya, begitu mudah jatuh cinta dan menyerahkan dirinya kepada lawan jenis.

Ketika dia bertemu Hasto yang merupakan calon anggota DPR, dia langsung merasa tertarik. Selain kaya, Hasto ternyata orang kaya. Ketika Hasto pada akhirnya memperalat dan memanfaatkan kenaifannya, Erna tidak bisa melakukan apa pun. Setelah ditiduri lelaki itu, dia dicampakkan. Erna sama sekali tidak tahu kalau Hasto sudah berkeluarga. Ketika dia dan Hasto sedang berada di kamar sebuah hotel, tiba-tiba saja istri Hasto datang dan melabraknya.

Lalu Erna pun kemudian jatuh ke dalam pelukan Rafa yang sebenarnya sejak awal sudah tertarik pada gadis itu. Ketika Erna tidak punya harapan lagi terhadap Hasto, dia pun berharap pada Rafa. Hubungan mereka membuat Erna hamil. Sebenarnya Rafa ingin bertanggung jawab. Tetapi perseteruan politiknya antara dia dengan Pakde Lamin, ayah Erna, membuat Rafa 
memilih meninggalkannya setelah dia menjual Erna kepada Topan yang akhirnya memperkosa Erna saat perempuan ini tidak sadar karena pengaruh minuman keras. Karena Erna juga dekat dengan Bagus, teman sekelasnya, Pakde Lamin menuduh Bagus yang menghamili Erna. Tetapi ternyata Bagus tidak tahu apa pun soal itu. Teman sekelas Erna yang jatuh cinta padanya ini hanya bisa merenungi nasib bahwa wanita yang dia cintai tidak seperti yang dia bayangkan. Erna sendiri, yang merasa hancur kehidupannya, memilih minggat dari rumah. Cerita novel ini pun berakhir di sini.

Dari kacamata sosiologi sastra, Erna tidak hanya merupakan seorang perempuan sebagai individu. Kalau sebuah novel merupakan cerminan kenyataan yang ditulis oleh pengarang, maka dalam konteks ini Erna bisa dianggap merupakan representasi dari para gadis muda yang mudah tergoda, terombang-ambing dalam ketidakpastian hidup dan kemiskinan, dan tidak memiliki pegangan moral yang baik. Pada akhirnya, gadis-gadis seperti ini akan menghancurkan hidup dan masa depan mereka sendiri.

Merujuk pada Clark (1982), sastra adalah diskursus sosial. Peristiwa-peristiwa yang ada di dalamnya merupakan akibat dari berbagai macam relasi yang ada di dalam masyarakat. Apa yang dialami atau terjadi pada Erna bukan semata-mata kesalahan dirinya sendiri. Tetapi mudahnya dia tergoda oleh duniawi, oleh bujuk-rayu kaum hidung belang, seperti dikisahkan Tulus Setiyadi, berakar dari kemiskinan dan bobroknya masyarakat modern kita dalam berbagai aspek, termasuk aspek sosial politik di negeri ini, termasuk kemunafikan kita dalam beragama.

Bisa saja kita berkilah bahwa orang miskin tidak harus tidak bermoral melainkan harus tetap menaati perintah dan larangan Tuhan. Tetapi kenyataan di masyarakat bisa berbeda dari hal-hal ideal yang kita konsepsikan. Bisa saja Erna bukan hanya merupakan tokoh dalam sebuah novel melainkan ada di dalam kehidupan nyata di sekitar kita. Adalah tanggung jawab kita semua sebagai anggota masyarakat untuk memberikan pendidikan yang baik, termasuk contoh yang baik bagi generasi muda agar mereka memiliki pegangan hidup yang kuat, tidak mudah tergoda atau terombang-ambing dalam kehidupan modern yang sarat dengan godaan.

\section{SIMPULAN}

Sekalipun merupakan cerita fiksi, novel dan karya sastra pada umumnya merupakan refleksi dari masalah-masalah sosial kemasyarakatan yang dituangkan oleh pengarangnya dalam sebuah kisah. Pendekatan sosiologi sastra yang digunakan dalam penelitian ini menunjukkan bahwa novel MKISPP mengandung berbagai permasalahan sosial yang terjadi dalam masyarakat pedesaan Jawa modern. Keadaan ekonomi tokoh utama yang berada di kelas bawah tidak menjadikannya menerima keadaan begitu saja. Erna, yang merupakan representasi perempuan Jawa modern dari kelas bawah, berusaha melakukan pemberontakan terhadap kemiskinan dan kondisi ekonominya yang sulit dengan berbagai cara yang bahkan melanggar norma sosial dalam masyarakat. Namun, pada akhirnya kekuasaan, politik, dan kekayaan justru membuat Erna menjadi korban atas kemiskinan dan pria kaya berkuasa yang tidak bermoral.

Untuk mengetahui secara komprehensif persoalan ini, idealnya memang pendekatan atau teori yang digunakan dalam penelitian ini mencakup sosiologi pengarang, sosiologi karya, dan sosiologi pembaca. Tetapi karena keterbatasan waktu dan biaya, peneliti hanya fokus pada pendekatan sosiologi karya. Untuk penelitian berikutnya dari perspektif sosiologis, topik yang bisa diangkat dalam 
meneliti novel ini perlu atau bisa melibatkan pengarang, pembaca atau keduanya agar diperoleh hasil yang lebih komprehensif.

\section{DAFTAR PUSTAKA}

Abrams, M. H. (1953). The Mirror and the Lamp: Romantic Theory and the Critical Tradition.

Aisyah, S. N., \& Widodo, W. (2019). Citra Perempuan dan Bias Gender dalam Novel Juminem Dodolan Tempe Karya Tulus Setiyadi. Sutasoma: Jurnal Sastra Jawa, 7(1), 1-6.

Al Hafis, R. I., \& Yogia, M. A. (2017). Abuse of Power: Tinjauan Terhadap Penyalahgunaan Kekuasaan oleh Pejabat Publik di Indonesia. Publika: Jurnal Ilmu Administrasi Publik, 3(1), 80-88.

Ansori, M. H. (2020). Wabah COVID-19 dan Kelas Sosial di Indonesia. THC Insights, No. 14/06 April/ diunduh dari www.habibiecenter.or.id

Ardiyanti, M., Sulanjari, B., \& Zaidah, N. (2020, Oktober). Aspek Sosial dalam Novel Cinencang Lawe Karya Tulus Setiyadi Kajian Sosiologi Sastra. Dalam Seminar Nasional Bahasa, Sastra, Budaya Daerah, dan Pembelajarannya (Vol. 1, No. 1, 133142).

Astutik, E. P., \& Hasan, L. N. (2018). Rasa Cilik Atine Paraga Sajrone Novel Cinencang Lawe Anggitane Tulus Setiyadi (Tintingan Psikologi Individual Alfred Adler). Baradha, 2(2), 1-13.

Cahya, I. N. N. (2017). Novel Juminem Dodolan Tempe Anggitane Tulus Setiyadi (tintingan Sosiologi Sastra). Baradha, 3(3), 1-18.

Calinescu, M. (1982). Literature and Politics. Dalam Jean-Pierre Barricelli dan Joseph Gibaldi. Interrelations of Literature. New York: The Modern Language Association of America, 123-149.
Clark, P. B. P. (1982). Literature and Sociology. Dalam Jean-Pierre Barricelli dan Joseph Gibaldi. Interrelations of Literature. New York: The Modern Language Association of America, 107-122.

Endraswara, S. (2011). Metode Penelitian Sosiologi Sastra. Yogyakarta: Caps.

Faruk. (2017). Pengantar Sosiologi Sastra. Yogyakarta: Pustaka Pelajar.

Harjani, P. R., Suwandi, S., \& Wardhani, N. E. (2018, Maret). Konflik Batin Tokoh Utama Novel Ontran-Ontran Sarinem Karya Tulus S. Dalam Seminar Nasional Bahasa, Sastra Daerah, dan Pembelajarannya.

Hartanto, J. S. (2003). Kasurung Wuyung. Panjebar Semangat No. 28, 12 Juli.

Kinatri. (2003). Pak Mikir. Panjebar Semangat No. 21, 24 Mei.

Margono, Y. B. (2020). Maca Gegutitan ing Amerika: Antologi Esai Sastra Jawa Modern. Semarang: Sint Publishing.

Masdjup. (2003). Kobong. Panjebar Semangat No. 20, 17 Mei.

Moleong, L. J. (2007). Metodologi Penelitian Kualitatif. Bandung: Rosdakarya.

Murenda, E. (2020). Citrane Wanita Mandhiri Sajrone Novel Kendhaga Benthet Anggitane Tulus Setiyadi (Tintingan Feminisme). Baradha, 14(5).

Ragilputra, T. (2007). Bledheg Segala Kidul: Antologi Geguritan (19872007). Yogyakarta: Gema Grafika.

Ratna, N. K. (2003). Paradigma Sosiologi Sastra. Yogyakarta: Pustaka Pelajar.

Ratna, N. K. (2008). Teori, Metode, dan Teknik Penelitian Sastra (Dari Strukturalisme Hingga Postrukturalisme, Perspektif Wacana Naratif). Yogyakarta: Pustaka Pelajar.

Ratna, N. K. (2011). Estetika Sastra dan Budaya. Yogyakarta: Pustaka Pelajar.

Setiyadi, T. (2019). Mecaki Katresnan ing Satengahe Perang Politik. Lamongan: CV. Pustaka Ilalang Group.

Sudadi. (2003a). Tangise Si Jabang Bayi. 
Praxis : Jurnal Sains, Teknologi, Masyarakat dan Jejaring | Vol. 3 | No. 2 | Maret 2021

Panjebar Semangat No. 23, 7 Juni.

Sudadi. (2003b). IMF (International Mortgage Fund). Panjebar Semangat No. 33, 16 Agustus.

Suharyono, A. Y. (2001). Sirah! Jakarta: Penerbit Wedatama Widya Sastra.

Wellek, R., \& Warren, A. (1956). Theory of Literature. New York: Harcourt, Brace \& World.

Wicaksono, A. (2014). Pengkajian Prosa

Fiksi. Bandung: Garudhwac 